\title{
フォーラム
}

\section{地理学ウィーク 2004}

人文地理学会が学界の研究成果を社会に還元する ことを目的として，2001年度より開始した「地理学 ウイーク：中・高校生のためのセミナー」は, 4 年 目を迎えた。本年度は，2004年 7 月19日に奈良県文 化会館（奈良市）を会場として開催した。

今回は,「インターネット時代の『地理』の魅力一 どれだけ私たちは『地理』を語れるか？一」という テーマを揭げ,「『郷土（ふるさと）』のみかた・と りかた・えがきかた」について，4名の会員に講演 と講義をお願いした。以下，それらの要旨を揭載する。

[付記] 本事業は, 平成16年度文部科学省科学研究 費補助金「研究成果公開促進費 [研究成果公開発表 (B)]」の助成を受けて開催された。

(人文地理学会地理学ウィーク企画委員会)

\section{ふるさと再発見一方法としての地理教育・郷土学} 習一

$$
\text { 小泉泰一（奈良大学） }
$$

\section{1.はじめに}

「地理教育」「地理学習」は, 学習指導要領に示さ れている通り, 小学校, 生活科, 社会科, 中学校地 理的分野, 高校地理へと継続性をもって発展的に進 行していく。览童生徒は, 自分たちの住む身近な地 域の学習から市町村 (区), 都道府県, 我が国の国土, 世界の諸地域の学習へとその発達段階に応じて, 各 ステージにおいて空間認識とともに地理的な見方考 え方を培っていくこととなっている。

「地理は暗記科目」「地理を指導する専門の先生が いない」「社会科（地歷科）の先生のなかでも地理を 敬遠する先生が多い」等々, 巷間, 指摘されてきた ところであるが, 地理を担当している教師自身が先 ずもって生徒に「地理の授業は楽しい」と実感させ られるような教育実践をしてこなかったことを自省 しなければならない。加えて地理が選択科目として 位置付けられ，地理を選択する生徒が極端に減少し ている現状も上記との関連において看過することは
できない。

そこで,「地理教育」「地理学習」の原点に立ち返 り，高等学校における郷土学習を通して「地理の授 業はやっぱり楽しい」と実感させられるような授業 実践について二つの事例から探ってみたい。

2.ふるさとに学ぶ

〈例 1〉市町村史を教材化する一文献調查を中心と した展開例一

市町村史の発刊時期は，明治以来概ね 4 段階に区 分することができるが, 発刊されている市町村史は 各々の時期にその地方に精通した研究者がかなりミ クロに調査研究を重ねた上で執筆, 上梓されたもの で，その資料性は高く評価されるものである。内容 的にも当該地域の自然環境，人口，産業，集落等が 一応網羅されているのが通例で, 多面的, 多角的な 活用に十分耐えうる教材的価值を有するものである。 そこで，具体的な文献資料として『奈良市史・地 理編』を取り上げ，(1)奈良市の中心市街地が形成さ れた時代的背景と要因を調べ，その形態を読みとる。 (2)奈良市の中心市街地は明治以降, 形態的機能的に どのように変貌したかを理解する。(3)市史から歴史 地理的資料を検索できる手立てを会得する。(4)郷土 に対する愛着と課題意識を喚起する。一を目標に掲 げて展開することとした。文献調査を中心とした展 開の場合, 生徒が個人又はグループで調査し, これ を発表させる方法と教師が資料を選択し, 指導計画 のなかに適宜挿入しながら進める場合が考えられる が,ここでは後者によった。

その際, 教師主導型の一斉授業になることを避け るため OHP 2 台用意し，これを交互に又は同時 に使用することによって地域の空間的時間的変貌の 理解を容易にさせ，授業の流れにも変化をもたせる よう心掛けた。

地方史の一部を授業に活用する際, 特に留意しな ければならないのは第一に教師自身が行う資料選択 の明確な視点と, 生徒に対する資料の提示方法であ る。いずれも学習目標に対応する資料の精選，展開 
時の資料の位置付けの最適化, その学習を通して生 徒にどのような力を付けさせたいのかという教師の 教材観, 指導観等の明確化が必要である。第二にや やもすれば一斉授業に陥りやすいこの種の授業では 仮に同一資料による一斉授業の形態であっても，そ の課程のなかに作図などの作業的な学習形態を取り 入れるなど授業の組み立てを工夫することが大切で ある。第三に地方史の多面的な活用という観点から 地理学習の各単元の中で, 市町村史に網羅されてい る各種資料（自然環境, 人口, 伝統的産業, 集落 等々）を適宜活用し，時に身近な地域に軸足を置い た学習を試みることも大切ではないかと考える。

〈例 2 〉歴史的風土での地理学習一野外調查を中心 とした展開例—

“飛鳥”については，生徒たちは日常的に様々な機 会に見聞しているところであるが，事前のアンケー トをみるとその認識程度, イメージは案外断片的で 浅薄なものである。そこで身近な地域・飛鳥を「地 理」で教材化することによって「歴史的風土への関 心」を高めさせるとともに飛鳥について論理的に整 理認識させ, 地理学習への興味関心を喚起させたい と考えたのがこの取り組みである。

本題材は,「明日香村の開発と保全」を主題に(1)明 日香村の保全（講義）(2)野外学習 (3)自由研究 (4) 発表・討議という指導計画に基づいて展開したもの である。その方法は通常の授業をすすめる中で部分 的に年間指導計画の組み替えを行い，上記(1)〜(4)を 変則的に挿入する形を取ることとした。

学習目標として (1)明日香村における歴史的風土 や地域景観を調べ，それらの保全がどのようになさ れているかを理解させる。(2)「開発と保全」の接点 を実証的に理解し, この問題に対する課題意識を持 たせる。一の 2 点においたが, 特に次の 3 点に留意 することとした。

(1)教室学習では法律, 条例の解釈や解説学習に陥 らないよう, 常に地域住民の生活環境, 生活条件な どに注目し，その社会的事象を具体的に取り扱うこ と。(2)野外学習はクラス単位で, 土曜日の午後に実 施することとし, 現地説明は地形環境を基盤に, 史 跡遺蹟分布, 道路 - 河川整備, 農業形態, 集落立地 等に関わるポイントを精選して行う。
以上の学習過程で得られた成果は, 様々なかたち で表わされてきた。一つは自由研究のテーマの変更 である。事前に提出させたテーマに比して歴史的風 土, 開発と保全, 人々のくらし等々をキーワードに 据えて個々の地理的事象を分析しようとするテーマ に変わってきたことである。いま一つは研究発表・ 討議に，歴史的風土という環境を基盤に人文地理的 視点, 自然地理的視点, 歴史地理的視点等が初歩的 ではあるが盛り込まれてきていることである。地理 学習におけるフィールドワークの重要性を改めて認 識させられるところである。

ただ，この種の授業実践では土曜日の午後の 4 時 間という時間的制約の問題があり，これをクリアす ることが必要であるが, 時間確保の問題は現状では 至難のことである。

\section{3.「総合的な学習の時間」地理教育}

平成15年度から高等学校でも「総合的な学習の時 間」(以下「総合的学習」) が本格的に実施され「各 学校は, 地域や学校, 生徒の実態に応じて, 横断的 総合的な学習や生徒の興味・関心等に基づく学習な ど創意工夫を生かした教育活動を行う」こととなっ ている。

地理（社会科）担当教師も当然のことながらその 中に組み込まれ，むしろ中心的役割を果たしながら その充実発展に寄与している。もとより地理（社会 科) 担当教師は「身近な地域」等の教材化等々を通 して調べ学習, 問題解決学習, 調査·研究, 発表 · 討議等を生徒の発達段階, 実態に配慮しながら, 講 義中心の授業の改善を目指し, 生徒の主体的学習を 重視する教育活動を重ねてきたところであるが, こ こにきて新参の「総合的学習」に地理教育のノウハ ウを奪い取られた感がしないでもない。

本来,「総合的学習」で培い養った資質, 能力, 態 度が各教科科目に敷衍され，すべての教育活動の活 性化に結びつくことが望ましいが, 昨今「総合的学 習」の時間にのみ華々しく力点がおかれるあまり地 理教育がまたまた注入，暗記科目に押しやられるの ではないかとの危惧が提起されている。地理教育地 理学習が目指す「地域の規模に応じて地理的事象を とらえ，その地域性を系統地理的，地誌的に多面的， 多角的に考察し, 生徒の空間的認識の拡大を図って 
いく」という原点を大切にし，「総合的学習」とは一 線を画した地理教育, 地理学習の創造が強く求めら れる。改めて「身近な地域」の学習を一つの契機と して地理を学ぶ喜び, 楽しさを実感させたいもので ある。

4. 4 つの提案

(1)小, 中, 高校教師が発達段階を踏まえた地理教育, 地理学習の「一貫性」を再確認しよう。

例えば高校地理では, 担当教師は中学校地理的分 野の学習内容と内容の取り扱い，その学習成果を(1) 教科書及び学習指導要領の点検, (2)既習事項の習熟 についての簡単なテスト，アンケートの実施等によ り確認すること。

(2)高校入試，大学入試問題の点検とこれに対する忌 憚のないアピールを積極的にしていこう。

入試問題が地理的技能（地理的な見方考え方及び 読図, 作図, 景観写真の読み取り等) や地域性の理 解, 認識に重点がおかれ, 基礎的基本的な地理的事 象が重視されているか否か, 細かな事象や高度な事 項, 事柄に踏み込んでいないか等の点検が必要である。 (3)年間指導計画の中で「身近な地域」にウエイトを かけ，必ず文献調查や野外学習の実施を位置付け, 地理の学び方を学ばせ, 見つけるよろこび, 表現す るよろこび等を実感させよう。

(4)教師手づくりの『地理学習ノート (仮称)』等を通 して, 地理の授業を“調べる, 書く（描く）, 発表す る”一学習の場にしていこう。

\section{記録としての写真}

石井 實 (イシイフォトライブラリー)

1839年 1 月, フランス学士院でルイ・ジャック . マンデ・ダゲール（1787-1851）によって, ダゲレオ タイプ (銀板写真) が発表されてからまた200年に満 たない。しかしこの銀板写真から湿板, 乾板, ロー ルフィルムと進化し, 現在では銀塩写真を凌ぐ勢い で普及しているデジタル写真まで，めざましい変化 と発展を続けている。日本で写真が定着するのは, 明治中期とされている。明治30年代からアマチュア の写真団体が全国的に誕生し, これが徐々に普及し ていった。地理学の分野でも写真は早くから利用さ れてきた。近年は成瀬厚 $(1997 \mathrm{a}, \mathrm{b})$. 沖 慶子
（2002）らの若い方たちによる写真の研究もみられ， 「地理写真」として市民権を得つつある。

「地誌は一日も精確なる能わずといふ。人文を記せ る地理に於て殊に然りと為す」「本書題して新撰名勝 地誌といふ。地誌と稱すと雖も，實は旅行案内記た り」ここれは田山花袋が1910年に出版した『新撰名勝 地誌』の巻之一『畿内之部』の凡例に記された文章 である。そして「地誌は地圖の如く，旅行記は絵畫 の如くならざるべからず。而して案内記は地圖と絵 畫とを兼ねざるべからず」と続く。すると写真は花 袋のいう絵画の役割と同じに考えてよいであろうか。 あるいは地図と絵画の中間に位置するのか。花袋は 写真についてどのように考えていたであろうか。一 般的には文法を持つ地図に対して，「あいまいな記 号」である写真は絵画と同じに考えることもできよう。

浮田典良（2004）は「田山花袋は1889年から 1912 年までの間（28４1歳）博文館に勤めて」いたと述 べ，花袋は1903年から『大日本地誌』の編集に関わ り,「余り売れ行きが好くなかったので, 段々書肆か ら継子扱いにされ」「退屈な写真の選択に二週も三週 もかかったりした」（田山花袋，1981）と書いている。 一口に写真と言ってもこの内容はさまざまである が，いわゆる芸術写真と記録写真とに分けて考えて よい。報告者が長年にわたって撮り続けてきたもの は，相当な部分が場所の経時的，あるいは空間的な 変化，また地理的事象に関わる記録写真である。こ れらの写真は地理学の研究資料として, また地理教 育の教材としても利用でき，現在，これをWebでの公 開を試みている (http://www.digital-lib.nttdocomo. co. jp/nihonbunka/machinami/ma_kikaku2. html 参照)。 記録としての写真の課題としては次の(1)(2がある。 (1)場所の変化の記録をみる

写真が地理書に掲載されたのは, 報告者の見たも のでは, 『日本名勝地誌』の第一編『畿内之部』(野 崎左文著・1893年）から第十二編『臺灣之部』(島田 定知著・1901年）までのシリーズである。第八編 『南海道之部』（野崎左文, 藤本藤蔭著, 1898年）ま では本文中に銅版画と思われる絵画が添えられてい るが，第九編『北海道之部』(松原岩五郎著, 1899 年）になって卷頭に小さな写真が 36 点がみられる。 なお『新撰名勝地誌』は銅版画と写真とがみられる 
が, 『日本名勝地誌』第一編『畿内之部』の189頁の 「平等院鳳凰堂」の図が,『新撰名勝地誌」の巻之一 『畿内之部』の149頁に掲載されている。すべての巻 に写真が掲載されるのは1903年から1915年にかけて 完結した『大日本地誌』（全10巻）でここには1667 点もの写真がある。巻 1 から全 10 巻の刊行までに 10 余年を経過しており, 全巻を通してみると写真表現 や内容, あるいはレイアウトなどが変化しており， タイムラグを持ちながらも写真界の動きを反映して いることが分かる。今回は巻 1 『関東』と巻 4 『近 畿』に揭載されている写真の内容について気づくこ とを少し見て頂く。関東では特に建造物が多く, 例 えば第三十九圖甲の「東京府廳全市役所」について は「有楽町一區の地は更にさまざまなる數箇の洋館 を屹立せしむ。東京府廳は中央に一箇の塔を有して， 一見人をしてその特色を忘れさらしめ……と記述 され, 多くの洋風建築の写真がみられる。小林清親 の描いた「東京名所図」（1873）中の「海運橋（第一 銀行雪中)」の絵は，まさに「文明開化の殿堂」であ り，「江戸空間の中に押し入ってきた文明開化のさま ざまなシンボル」(前田 愛, 1992) としての建築が この『大日本地誌』にも揭載されたことが巻 1 の写 真に目立つ。これに対し近畿の写真は, 洋風建築も あるが,「明治後期から大正時代を経て昭和初期に至 る時代に，主にアマチュア（素人）写真家たちによ って制作された, 絵画的効果を重視するような写真 群の総称」（飯沢耕太郎，1986）が多く見られる。関 西においてこのような写真の代表的な写真家が, 京 都府の呉服商の家に生まれた黒川翠山（種次郎, 1882-1944）であった。黒川は『大日本地誌』の発行 元である「博文館写真部京都支部として同社の写真 の仕事を」し「山水画を思わせる風景写真や名所風 景の写真によって一時代を画する芸術写真のかたち をつくり出した」と金子隆一（1992）は述べている。 当時, 大阪市心斎橋の写真器械商, 桑田商会は 1904 年に「写真例題集」を発行し,アマチュアの応募作 品を揭載した。応募者は関西在住者が多く，黒川も これに多くの作品を発表している。「写真例題集」に は当然, 輸入されたレンズや乾板などの写真材料な どや旅館の広告。「秋は来れり撮影旅行の最好時 機」などの旅行案内なども揭載され, 当時の撮影地
として「保津川」「巨椋池」などが人々を集めた。な お当時感光材料が乾板であり, 大きな撮影器財とと もに持参できる感光材料も10枚程度。そのために乾 板を枠に入れ替えるための暗室が必要であった。旅 館の広告には「暗室の設備あり」という文言もみら れ，時代を物語っている。

『大日本地誌』巻 4 には「保津川」が 3 点（丹波國 保津川・丹波國保津川急湍・保津川の下流)，「巨椋 池」が1点みられるが, いずれも日本的な風景表現 と言える写真である。「山城國桂川の木材」の写真に は「大堰川流域と, 由良川流域との二つとなる。大 堰川流域森林は, 古来其流筏の便を得て, 伐出に容 易に, 今に至るも, 洛外嵐山の山腰渡月橋下に繋る もの多きを見るべし」に続き「製材業大いに振興し 来り」とあり，嵐山近くに製材業が多く立地した。 現在の状況を示したい。なお『大日本地誌』の帯に は，「地方誌」の中に「都府を中心にして，其附近の 名勝, 古蹟, 神社, 佛閣等を記し, 其他の地理的形 勢に就き, 最も其の精を極めたり。殊に材料は皆最 新にして最精確なるものを選びたれば，一面最良の 地誌たると共に, また旅客の爲に好案内記たらんこ とを期す。」との記載がみられる。巻 4 『近畿』には 209点の写真があり, 因みに奈良県は41点, このうち 薬師寺 5 点, 法隆寺 - 東大寺とも 4 点など, 陵墓や 寺社が30点を占めている。なお『日本名勝地誌』, 『大日本地誌』, 『新撰名勝地誌』の出版元はすべて博 文館であり，社主の大橋新太郎（又太郎）は写真も 撮影し，『千山萬水』(1899年)，『続千山萬水』（1900 年）の旅行記を出版した。そして鐵道省編『温泉案 内』（1931）や『鐵道旅行案内』（1936）など昭和 10 年代まで多くの旅行案内書を出版している。

\section{(2)写真から情報を読み取る}

写真には実に多くの情報が取り込まれている。写 真を読む場合，隅々まで目を通すことが必要である。 同じ場所の季節的変化（軽井沢）・上越国境の天気境 界・日向と日陰・偏形樹など時間の許す範囲で,さ まざまな写真を見て，どのようなことを読み取るか， あるいは理解できるかを考えて頂きたい。

「現代は映像の時代」といわれて久しいが, 非言語 的なコミユニケーション機能が映像であるともいわ れる。当然, 地図・写真・絵画などは映像であり, 
これらは一挙にすべてが提示され，記号論でいう 「現示性」という性質をもつ。ただし地図は殆どが一 定の約束事に基づいて表現されている。これに対し 写真は，地図製作の目的で撮影されるような特殊な ものを除いて，一般的に撮影者の意志によって恣意 的に撮影される。そのために約束事のない「あいま いな記号」(名取, 1964) であり，しかも「目の高さ からの」(島津, 1992) 風景が極めて多い。というこ とは地図から受けるイメージと写真から受けるイメ ージとの相違も考えねばならない。写真も地図もそ れを読む人それぞれの知識・経験・文化的背景など さまざまなものをべースに接することになる。例え ば寺院は地形図などでは札で示している。そしてこ の羽によって読図者は自分の知っている寺院の姿を 思い浮かべるであろう。村落にあっては民家よりも 大きく高い瞢の屋根をもつ建造物が寺院であること が多い。しかし最近では東京のような大都市の中心 部に位置する寺院では, 高層ビルに隠れてしまった ような寺院, あるいは高層ビルに変わった寺院も少 なくない。このことは場所に関するさまざまな情報 を得ようとする場合に，地図と写真はそれぞれ特有 な役割を持っていることに気がつく。すなわち地図 と写真は補完関係にあるということができる。

殆どの地図には場所を示す図幅名と測量年代が記 入されている。しかし写真では撮影場所, 撮影年月 日の記載がないものが大変多い。記録としての写真 にあって重要なことは「いつ」・「どこで」と，「何を 写したか (テーマ)」を記録をすることである。さら に必要な写真を直ぐに取り出すことができることで ある。写真は整理学である。保存されている写真の 検索を可能にするデータベースの構築は, 撮影より もはるかに時間を必要とする意外に面倒な作業であ るということもふれておきたい。報告者はできる限 り写真の整理を行ってきたが, 完全なデータベース ではない。経験的に言えば, 各人が利用目的に応じ たデータベースの構築を考えることになる。

次に撮影についてふれたい。ある目的で写真を撮 影する場合, 当然なことであるが, 撮影者は被写体 に向き合う。佐藤健二（1994）は，「描くというプロ セスで〈認識〉へと変化すべき〈経験〉を構成して いるが，写真はややもすると綿密な観察の記憶を作
り上げることなく終わってしまうのは, カメラがそ うした過程を必要としないからである」という。さ らに佐藤は「写真やコピーの多用が陥りがちな漠然 とした観察に対し，スケッチはつねに対象をこまか く見つめることを要請する」という。ここで撮影に 際して考慮すべきことは,「カメラがそうした過程を 必要としない云々」の部分である。この表現では, 写真は全く気軽に撮っていると述べているようであ るが，果たしてそうであろうか。横江文憲（1997） は, 19〜20世紀の写真家，アルフレッド・ステーグ リッツが, 1893年 2 月 22 日に厳しい冬のなかで最も ふさわしい時を 3 時間立ちつくして待って《冬・五 番街》の名作を残したと述べている。

ここで報告者は「シャッター以前」の語を思い起 こす。すなわち，どのようにフレーム内の処理をす るか, 必要と思われるものが完全に写し込めるか, 表現すべき重要な部分の欠落はないか, 最も重要な ことは，ノイズの排除がなされているかである。こ のために撮影位置の決定から始まって, カメラアン グル，レンズ，時には使用するフィルムの選定まで 考えることが必要になる。これら様々なことを充分 に考え，それからシャッターを切る。これが「綿密 な観察」であり，「認識」することではないだろうか。 中村和郎（1976）は科学研究に抢ける事実の記述, 分類, 説明の 3 段階の図を示しているが, これをも とに地理学において写真の役割と限界を当てはめて みたものが下図「地理写真の役割と限界」(石井, 1988を一部訂正）である (挿図割愛)。

一方，撮影者がさまざまな考慮のもとで撮られた 写真であっても，写真から情報を読み取る立場から 考えると「撮影の状況から切り離され，写真そのも のの画像のみと向き合う」ことになり，「フレームの 限界を超えることはできない」（成瀬，1997）ことで ある。ここでキャプションが問題となる。名取洋之 助（1963）は「写真は写しただけでは完成し」ない。 「とくに,コミユニケーションの手段として写真を使 う場合, 写しただけの写真は, 未完成品です。説明 のつけかたひとつで, 写真は逆にも読める」「写真を どう読むか。そのいとぐちをつけるのがキャプショ ン」であるという。坂川栄治（2002）は「写真を見 終えてから解説を読んだ。すると解説を読む前と後 
とでは, ブランクーシ (彫刻家) の写真も写真その ものの見方もすっかり変わってしまった」と述べ, 続けて「写真というものはキャプションや解説が付 かなければ，見る側は一方的な映像を差し出される ままに受け入れるしかない怖さを持っている。また 受け手はキャプションがなければ一方的な自分流の 解釈で写真を読み取ることもできてしまうという二 重の怖さを持っていることに気がつく。もっともそ のキャプションすらも置く位置を間違えれば, まる っきり違った情報になる怖さを秘めてはいるけれど も」と述べる。写真はすべてを一挙に示し, 黙った まま存在している。ということでは地図と全く同じ であり, ヴィジアルと呼ばれる非言語的なものに共 通する。「物言わぬ写真は, 文字情報と結びつくこと によって，にわかに雄弁になる」と斉藤多喜夫 （2004）は述べるが, 一方，「画像のみしか与えられ ないことが, 鑑賞行為を自由なものにする」（成瀬, 1997）し, ソンタグ（1979）は「キャプションは私 たちの眼の証言を踏みにじる傾向がある。しかしど んなキャプションも，写真の意味を永久に制約した り，保証したりすることはできない」とも述べてい る。長年写真を撮影・利用してきた報告者としては, それぞれの写真からその意図を正確に受け止めて欲 しい, 換言すれば共同主観の成立を期待したいとい う願いも达めているのである。これは欲の深いこと であろうか。

〈参考文献〉

飯沢耕太郎（1986）：『「芸術写真」とその時代』, 筑摩書房, $255 \mathrm{p}$.

飯沢耕太郎 (1996)：『写真美術館へようこそ』, 講 談社, 235p.

石井 實（1983）：日本における地理写真の発達に 関する研究。地理学評論, vol. 56, pp. 449-470.

石井 實 : (1988)『地理写真』, 古今書院, $254 \mathrm{p}$. 石井 實 (1989) :『地と図一地理の風景一』, 朝倉 書店, $176 \mathrm{p}$.

石井 實（1998）：地理写真再考一「『地と図』を 読む」を読んで一, 地理科学, vol53, pp. 46-59.

石井 實（1999）：『地理の風景一古代から現代ま で一』, 大明堂, 190p.

石井 實 (2001)：『写真集・東京 都市の変貌の
物語1948-2000』， KK ベストセラーズ, 200p.

浮田典良 (2004)：ブックサーフィンー地理学の名 著を訪ねて一（1900-1969），「地理」，49-10, p. 129. 金子隆一（1992）：日本のピクトリアリズムー風景 へのまなざし一，東京都写真美術館，財団法人 東 京都文化振興会, 140 p.

斉藤多喜夫 (2004) :『幕末明治 横浜写真館物語』, 吉川弘文館, $219 \mathrm{p}$.

佐藤健二 (1994) : 『風景の生産・風景の解放 メ デイアのルケオロジー』, 講談社, $258 \mathrm{p}$.

坂川栄治 (2002) : 『写真生活』, 晶文社, $154 \mathrm{p}$.

島津俊之 (1992)：可視的世界からの接近, 愛知大 学綜合郷土研究所編, 『景観から地域像をよむ』, 名 著出版, pp. 157-161.

田山花袋編（1910-）:『新撰名勝地誌』, 全12巻, 博文館, $500 \sim 600$ p.

田山花袋（1981）:『東京の三十年』, 岩波書店, 334p.

中村和郎・梶川勇作・寺阪昭信（1976）：新しい地 理学への道, 「人文地理」, 28-5, pp. 508-531.

名取洋之助：(1964）『写真の読み方』, 岩波書店, $205 \mathrm{p}$.

成瀬 厚（1997a）：レンズを通した世界秩序一世 界の人々をテーマにした写真集の分析から一，人文 地理, vol. 49, pp. 1-19.

成瀬 厚 (1997b) :『地と図』を読む,「地理科学」, 52-2, pp. 39-49.

野崎左文ほか（1893-）:『日本名勝地誌』, 全12巻, 博文館, $400 \sim 550 \mathrm{p}$.

前田 愛（1992）：『都市空間の中の文学』，筑摩書 房, $664 \mathrm{p}$.

横江文憲（1997）：アルフレッド・ステーグリッッ 一写真家としての軌跡, 東京都写真美術館, pp. 1518.『アルフレッド・ステーグリッツとその仲間た ち』, 財団法人東京都文化振興会。

山崎直方 ·佐藤伝蔵（1903-1915）：『大日本地誌』, 全10巻, 博文館, 700 1200p.

スーザン・ソンタグ著, 近藤耕人訳 (1979) : 『写 真論』, 晶文社, 221p. (Susan Sontag (1977) : “ON PHOTOGRAPHY”.) 
ことばの広がりことばの響き一富山県音声言語地

図をもとに一

$$
\text { 中井精一 (富山大学) }
$$

1. 日本語の地理的ひろがりと富山県方言

各地で日々使用されていることばを地域ごとに分 類する場合, 音韻・アクセント・文法・語彙などに 認められる特徵に注意して，方言を区画するのが一 般的である。

日本語の方言区画では, 本土方言と琉球方言の二 つに大きく分けるというのが通説になっている。琉 球方言は，ひとことでいって非常に特徴ある方言で, 多くの島々の方言同士が対立の様相を呈している。 したがって, 場合によっては島が違うと一言もわか らないといったこともある。琉球方言は, 大別して 奄美・沖縄・先島の三方言に分けることができる。

次に本土方言は，大きく東部と西部・九州の三方 言に分類できるが，富山県方言との関連では，東部 方言と西部方言がその方言的特徴に影響を与えてい る。大枠に従いながら, 顕著な特徵を見せる諸方言 について具体的に述べると, 現代日本標準語の基盤 となっている東京語を合む東部方言のなかで, 特に 標準語と異なった特色を示すのは, やはり東北方言 である。

東北方言は，音韻の面では，イとエの区別がなく 中間的な音【ẹ】で，またシとス，ジとズなどの区別 がなく，ともに中間的な音で発音される。さらにカ 行・夕行の音が語中にある場合, ツグイ (机), カダ (肩) のように濁音化する。このような東北方言の音 声的特徵が西部方言域にある富山県方言でも顕著に 認められる。

文法の面では, 推量・勧誘·意志を示す「ベー」, 「東京サ行く」のように方向・場所を表す助詞「サ」 の存在などが東北方言の特徵であるが, 富山県方言 では認められない。

西部方言では，アクセントなどで東京方言ときれ いな型の対立を見せる近畿方言を代表例に示すと, 音韻の面では，無声化が少なく，また一音節の語が, テー（手）ハー（歯）のように長音化する。

文法の面では, 断定·打消・待遇・命令などの表 現が東部方言・標準語と異なる。例えば,エエーテン キャ〈いい天気だ〉, 夕ベヘン〈食べない〉, タベハ
ル〈お食べになる〉, ミヨ〈見ろ〉のような特徴を見 せる。このような近畿方言（西部方言）の文法的特 徴は，富山県方言でも認めることができる。

以上のように, 富山県は, 日本の東西方言を分け る境界付近に位置することから, 東西両方言の影響 を顕著にみせる地域と言える。

\section{2 . 音声言語地図の特徵と意味}

私たちがこの世に誕生し，両親や家族から最初に かけられることばは，母語・方言であることは誰も が理解できるであろう。人は, 家族や近隣の人々と 話し言葉である方言を用いてコミュニケーションを 行い, 社会で暮らしていくための知識やルールを方 言によって深めていく。

コミュニケーションには, 話す・聞く・読む・書 くという 4 つの柱があるが，「読む・書く」という書 き言葉は, 公的な教育によって習得されるもので, 「話す・聞く」という話し言葉こそが生得的なコミュ ニケーションの柱である。そして「話す・聞く」に は「音声」という要素が不可欠であって，「音声」を 伴わないコミュニケーションというのは副次的と言 わざるを得ない。

日本語の研究が, 過去の文献や遺跡から出土する 金石文や木簡などの資料をもとにした，副次的な書 き言葉の研究が中心であった時代は終わった。それ にかわって現代語を中心とした話し言葉やコミュニ ケーションなどの言語行動に研究の関心が移るなか で, 話し言葉を収集し, 収集・分析した「音声」を 「音声」のままで公開することが望まれるようになっ た。

こういった要請は, パーソナルコンピューターの 飛躍的な性能の向上と価格の低下により人文系研究 者の多くがパーソナルコンピューターを所持し, 相 互に協力しながらデータの共有や谷謙二氏開発の MANADARAに代表されるようなソフトの無償配 布などによってリテラシーの向上が背景に存在する。

音声言語地図は，地図上の記号をクリックすれば その地点の実際の音声が再現される「声による言語 地図」である。これによって調査・分析をした研究 者以外の人々にも, 臨地そのままに実際の音声を聞 くことが可能なため, これまでにはないような多様 で有益な情報の提供が期待され, 研究を大きく前進 
させる可能性をもつと考えられる。

3.「富山県音声言語地図」の作成について

「富山県音声言語地図」では,

(1) GIS ソフトである MANDARA を利用して，音声 を伴わない「富山県言語地図」を作製した。

(2) MANDARA で作製した地図をpdf ファイルに変 換し，音声を貼り付ける。

1）音声の取り込み

2 ) 音声の加工

3 ) 音声を貼り付ける

4) フォントを埋め达む

5 ）音声を再生する

なお，言語地図の凡例に使用している記号のフォ ントは「言語朗君」(徳島大学総合科学部岸江研究室 の石田祐子さん作製）を使用している。

4.「富山県音声言語地図」から見た富山県のことば 富山県は，日本の東西方言の狭間にあって，また 日本海側にあって，ここではさまざまな地域方言の 特徵を見ることが出来る。その特徵は, 音声言語地 罒によってよりはっきりとしてきた。

(「富山県音声言語地図」は, 富山大学人文学部中 井研究室のホームページ,「調查成果」よりダウンロ ードください。http : // www. hmt. toyama-u. ac. jp / nihon / framepagel. htm)

たとえば,「アイウエオ」の発声について考えてみ ると（音声言語地図「アイウエオ」参照），人が「ア イウエオ」と言う場合, 高低のアクセントやイの音 とエの音が近いなど音韻による特徵を感じることが できる。日本語の標準的な母音は「アイウエオ」の 5 つと言われるが, 東北や日本海沿岸地域では, エ の音とイの音が入れ替わったり，混同されるような ことがよくあって,「アエウイオ」や「アイウエオ」, 「アエウエオ」というような発声になるといったこと がある。このような現象は，「富山県音声言語地図」 でも確認できる。

また，イの音とウの音の関係では，(音声言語地図 「獅子舞を見る」参照）イ段のシの音とウ段のス音の 中間的な中舌母音のスィという発音である「スイス イ舞を見る」が，確認できる。

このほか, 「富山県音声言語地図」では, 単語のア クセントや「塩辛い」「とうもろこし」「とんぼな
どの方言語彙などの分布図が収録されていて，地図 上の記号をクリックすることで, 誰もが簡単にその 地域の生の方言にふれることができる。

5. 音声原語地図がひらく研究・教育の世界

音声言語地図は, 大学の音声学の教材として 記 号と実際の音声とを交互に示しながら音声の文字化 について教育することができる。音声の地理的なバ リエーションを扱う「音声原語地図」の場合, 一般 の音声学のテキストとは異なり, 地域の差異を通し て文字化の方法を学ぶことも可能になる。フィール ド調査の事前指導の教材としても最適である。

また, 小中学校の総合教育の教材や博物館の展示 にも利用が可能で, 作成が簡単で費用も安く, 簡単 に更新できるという利点によって，無限の利用の可 能性を秘めているといってよいだろう。

〈関連文献〉

岸江信介・木部暢子・石田祐子（2002）「声の言語 地図」『日本語学』9 月号明治書院。

鳥谷善史 (2002)「電子化言語地図の現状と問題 点」『日本語研究センター報告』vol. 10。

鳥谷善史 (2002)「「地図情報分析支援システム 『MANDARA』を使っての言語地図作成一『大阪府 言語地図』を作成する」『地域言語』第14号。

中井精一・坂口直樹（2000）「データベースソフト による富山県言語動態地図の作製について」『富山大 学人文学部紀要』第33号。

\section{フィールドワークの魅力一ベトナムの農村から一} 筒井 由起乃 (追手門学院大学)

1.フィールドワークとベトナムと私

「ベトナムの農村でフィールドワークをしている」 というと，十中八九，「何でまた？」と問い返される。 「ベトナム」は最近なぜか人気があり, 陶器や竹製品 などの雑貨や，フォー（ベトナムうどん）などの料 理や，民族衣装のアオザイがもてはやされているか ら，「ベトナムへ行くこと」はうらやましがられるこ ともあるが, 発展途上の「農村」でしかも「フィー ルドワーク」とくると，たいてい怪訝な顔をされる。 フィールドワークは, 文化人類学の分野で19世紀 末に生み出された研究方法である。文化の異なる社 会に長期間住み込み, 現地語を学び, 人々の活動場 
面（狩猟，農耕，宗教儀礼，争議，祝祭など）に参 加しながら知識を得ていくというやり方である。私 の場合，「ベトナム農村に長期間に住み込み, ベトナ ム語を学び…ということになるわけで, 怪訝な顔 をされるのも領ける気がする。

しかし，これは少し違う。フィールドワークはも っと広い意味でも使われ, 研究室内でのデスクワー クではない, 野外の調查研究活動全般を指すからで ある。私の場合も調查対象はその農村内で完結する のではなく, 隣村や近くの町, ハノイへ広がってい った。

一ロに「フィールドワーク」といっても, 野外で の調査研究活動全般となれば，そのあり方はさまざ まである。地理学ではどのようなフィールドワーク が行われているのであろうか。最近の動向を示すも のとして, 『地理』の 48 巻 4 号〜11号（2003年）から 49 巻 $1 \sim 2$ 号 (2004年) で連載された「はじめての フィールド調查一現場で学ぶフィールド調査の技 術」をとりあげてみよう。10回連載のタイトルには， 「本にないフィールド技術」「農山漁村調査の現場」 「都市における社会調査」「企業へのインタビュー調 查」「流通業への聞取り調查入門」「個人によるアン ケート調查の現場」「飛び込みインタビューの調査現 場」「ジェンダーに関する調査入門」「若者文化への 調査アプローチ」「フィールドとの『距離』と『つな がり』」があり，調査内容にくわえて，都市か農村か という「現場」の属性や，個人か団体かという調查 対象の属性も異なっている。私がここでフィールド ワークの事例として用いるのはベトナム農村であり， 日本農村と異なる点もあるが, 大きくは「農山漁村 調査の現場」に分類されうる。

それではフィールドワークはまったく捉えどころ がないのかというと，そうでもない。フィールドワ 一クは「現場」ありきであり, 調査者が「現場」と どう向き合うかという姿勢が問われる作業であると 私は考える。だからこそ研究方法としてフィールド ワークを重視していながら, 個々のフィールドワー ク技術を一般化することが難しいのだろうし, 個々 の「現場」と自分との関わり方を模索する興味深さ があるのではないだろうか。

ここでは，このような視点にたって，「現場」とし
てのベトナム農村の魅力やフィールドワークの魅力 を示してみたい。

2.「現場」としてのベトナム

私のフィールドワークの「現場」としてのベトナ ムについて，簡単に説明して抢こう。ベトナムは東 南アジア地域に含まれるが，文化的には中国の影響 を強く受けている。たとえば食事には箸を使うし， 首都ハノイは漢字で表記すると「河内」である。文 化の基層に中国文化の影響がみられる点では日本と 共通している。したがって, しばしば日本はべトナ ムの比較対象になる。

ベトナムは社会主義国であるが，1986年から市場 経済化を進めている。ドイモイと総称される新しい 動きは経済面にとどまらず多方面に波及しており， 徐々に自由化・民主化が広がっている。ベトナムに おける自由化・民主化は，さまざまな機会の拡大で あると同時に自己負担の増加でもあり，起業の機会 や就業機会が増え, 物流が活発になった反面, それ まで無償であった教育費や医療費は基本的に受益者 負担に切り替えられた。当然ながら時流にうまく乗 って成功する者とそうでない者が出現し, 結果とし て国民間で経済的格差が広がっている。

それではこのような動向を農村レベルで捉えた場 合，どのような傾向がみられるのであろうか。それ を探求しょうとするのが, 私のフィールドワークで ある。

\section{3. 私のフィールドワーク}

私はある農村で, 農家の経済状況について調べる ことにした。その結果, 農家の経済的格差は主に農 業以外の副業によって生じており, 副業は, フォー などの食品加工業, 陶器の製造といった手工芸や, 出稼ぎなど多岐にわたっていることがわかった。そ うした事柄を把握するために, 私は農村を歩いて, 農家を回って話を聞き，役場に赴いて資料を集めた。 以下に私のある典型的な一日の様子をおおおまかに記 してみよう。

6 時 : 起床

6 時半: 朝食

7 時 : バイクで移動（調査農村から県庁所在地 ヘ)

8 時 $:$ 県で挨拶まわり 
8 時半 : 県農業部会議に参加

10時半 : 会議参加者の懇親会に参加

12 時半 : 昼寝

13時半：バイクで移動（県庁所在地から調査農村 へ)

14時半 : 村の役所で調査

16時：農家で聞き取り調査

17時半 : 㷌宅

18時：村民と夕食

21時：ノート整理

23時 : 就寝

県や村など公的機関への訪問に多くの時間をさい ていることがみてとれる。政治的にはまだ社会主義 体制を保持するべトナムでは，私的な調査は認めら れていない。したがって貴重な調査時間が削られて も致し方ないと半ばあきらめ開き直っていたが（農 家で聞き取り調査を行う際にも監視役がつく），しだ いにこれを逆に利用すれば，県や村のレベル統計資 料などを入手することも可能であることがわかって きた。当初, 形式的になりがちだったお役所訪問も, このメリットを知ってから，俄然積極的にこなすよ うになった。扮役所とはいえ，相手をしてくれるの は生身の人間である。何度も会って話をするうちに, びっくりするような資料をみせてくれたり, 話を聞 かせてくれたりする。調査対象者との信頼関係がい かに重要かということを幾度も思い知らされた。「現 場」においてこのような人間関係を築けるようにな ると, 相手は「ちょっと留守番してくれる? と頼 んでくるようになり，「今度いつ帰ってくる?」と見 送ってくれる。こちらも自然と○○村へ「行く」で はなく「帰る」という気になってくる。
4.フィールドワークの魅力

フィールドワークの魅力の一つは，そこが自分に とっていわば第二のふるさとのような存在になるこ とではないだろうか。村人の方もそれを受け入れて くれれば,なお素晴らしい。そうした関係を背景と して，村でおこる事柄の背景についてさまざまな想 像力を働かせられるようになる可能性があるからで ある。この想像力は,「現場」を捉える新たなフレー ムワークにもなりうる。

二つめの魅力は, その想像の真偽を確かめるため に，自分の足でさらにデー夕を集めることにあろう。 視角が明確になれば, デー夕収集もはかどるもので ある。

三つめの魅力は, 自分の想像したフレームワーク を自分で集めたデータで検証することにあろう。検 証する際に気をつけなければならないのは, 自分の フレームワークに固執し恣意的な結論を導かないよ うにすることである。そのためには,むしろ「現 場」と一定の距離を保つ必要があろう。つまり現地 調達ではない基軸が必要であると言い換えることも できる。基軸を定めるということは，研究者として の自身の視座を見据えなおすことであり，それ以前 に一人の人間としての自身を再考することでもある。 これはいってみれば自分の原点としての「ふるさ と」を見つめることでもあろう。そう考えると，フ

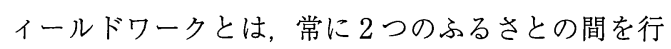
きつ戻りつしながら，両方のあり方に迫ろうとする ことなのかもしれない。

\section{【参考文献】}

杉本尚次『地理学とフィールドワーク』晃洋書房, 1996年。 